\title{
BIOMETRIC DIVERSITY OF FRUIT AND SEEDS OF BARBATIMÃO [Stryphnodendron adstringens (Mart.) Coville] IN NORTHERN MINAS GERAIS
}

\author{
Thaís Ferreira Bicalho ${ }^{1}$, Lorena Oliveira Barbosa ${ }^{2}$, Thaíse Ohana Moura Fernandes ${ }^{1}$, Ernane Ronie Martins ${ }^{3}$, \\ Verônica Satomi Kazama ${ }^{4}$, Solon Jonas Longhi ${ }^{5}$ \\ 1 Federal University of Minas Gerais, Graduate Program in Plant Production, Montes Claros, MG, Brazil - thaisfbicalho@outlook.com*; \\ thaiseohana@hotmail.com. \\ ${ }^{2}$ Federal University of Lavras, Graduate Program in Forest Engineering, Lavras, MG, Brazil - lorena.obarbosa@gmail.com \\ ${ }^{3}$ Federal University of Minas Gerais, Department of Agronomy, Montes Claros, MG, Brazil - ernane-martins@ufmg.br \\ ${ }^{4}$ Federal University of Paraná, Graduate Program in Forest Engineering, Curitiba, PR, Brazil - veronica.kazama@ gmail.com \\ ${ }^{5}$ Federal University of Santa Maria, Postgraduate Program in Forest Engineering, Santa Maria, RS, Brazil - longhi.solon@gmail.com
}

Received for publication: 20/10/2018 - Accepted for publication: 06/04/2019

\begin{abstract}
Resumo
A conservação, o emprego de técnicas de manejo sustentável e a elaboração de planos de manejo para extração do barbatimão são estratégias para reduzir sua exploração desenfreada e ameaça de extinção. O objetivo deste estudo foi caracterizar e verificar a diversidade biométrica dos frutos e sementes de diferentes localidades de coleta de barbatimão [Stryphnodendron adstringens (Mart.) Coville] no Norte de Minas Gerais. Os frutos utilizados foram coletados em nove localidades no Norte de Minas Gerais em agosto de 2014. Foram avaliados o peso, o comprimento e a largura dos frutos, e, nas sementes, o peso, o número de sementes por fruto, o número de sementes intactas, mal formadas e predadas. Os dados biométricos foram submetidos à análise multivariada de agrupamentos, discriminante e componentes principais. As localidades foram agrupadas em quatro grupos, sendo que o grupo 1, constituído pelas localidades MIR1 (Mirabela), BRM2 (Brasília de Minas) e MIR2 (Mirabela), apresentou as melhores características biométricas, sendo assim, indicado para seleção de matrizes. As variações morfológicas foram maiores dentro da localidade do que entre as localidades, e as variáveis mais importantes para o estudo de biometria das sementes foram o número de sementes por fruto, o peso das sementes e os números de sementes intactas e predadas.
\end{abstract}

Palavras-chave: Análise Multivariada, Biodiversidade, Biometria, Cerrado.

\begin{abstract}
Conservation, the use of sustainable management techniques and the development of management plans for the extraction of barbatimão are strategies to reduce their unbridled exploitation and threat of extinction. The aim of this study was to characterize and verify the biometric diversity of fruits and seeds from different localities for the collection of barbatimão [Stryphnodendron adstringens (Mart.) Coville] in the North of Minas Gerais. The fruits used were collected in nine locations in northern Minas Gerais in August 2014. The weight, length and width of the fruits were evaluated, and in the seeds, the weight, the number of seeds per fruit, the number of intact, malformed and predated seeds. Biometric data were submitted to multivariate analysis of clusters, discriminant and main components. The locations were grouped into four groups, and group 1, consisting of the locations MIR1 (Mirabela), BRM2 (Brasília de Minas) and MIR2 (Mirabela), presented the best biometric characteristics, being thus indicated for matrix selection. The morphological variations were greater within the locality than between the localities, and the most important variables for the study of seed biometrics were the number of seeds per fruit, the weight of the seeds and the numbers of intact and predated seeds.

Keywords: Multivariate Analysis, Biodiversity, Biometrics, Cerrado.
\end{abstract}

\section{INTRODUCTION}

The Cerrado, considered the second largest Brazilian biome, is classified as "hotspot of biodiversity", as it presents a high diversity of endemic species and has more than $70 \%$ of its natural area fragmented (BRASIL, 2018). The flora species, originating from this biome, are of great economic and social importance for the various sectors, deserving mention for pharmaceutical purposes (LOURENZANI et al., 2004). Among the native species of the Cerrado, Stryphnodendron adstringens (Mart.) Coville, popularly known as barbatimão, is a medicinal plant that has relevance in the treatments of burns and skin abrasions, due to the high tannins content in the bark, about 25 to $30 \%$ of its constitution (LORENZI, 2010).

Barbatimão populations, typical of the Cerrado sensu stricto, have a wide geographic distribution, covering areas of Pará, Central Plateau, Minas Gerais and São Paulo, at latitudes between 14 to $24^{\circ} \mathrm{S}$ and 
longitudes from 46 to $48^{\circ} \mathrm{W}$, average altitudes between 690 to $1000 \mathrm{~m}$, in two main phytophysiognomies, namely: Cerrado stricto sensu, with density ranging from 5.6 to 36 individuals per hectare, and Campo-Cerrado (CORREA et al., 2012; LORENZI, 2010).

In the last decades, there was a reduction in the production of barbatimão bark. Studies conducted by Borges Filho and Felfili (2003) relate this reduction to social factors, such as: indiscriminate advance of deforestation, expansion of urban centers and rural exodus, which affect the survival of these populations. Thus, conservation, the use of sustainable management techniques and the elaboration of handling plans for barbatimão extraction are strategies to reduce unrestrained exploitation and the threat of extinction (MEIRA et al., 2016).

The seed is the main medium for the multiplication of tree species. The knowledge about the production and technology of forest seeds assumes importance in the handling process, conservation and genetic improvement of these species. Thus, the choice of healthy parent plants, with good seed production capacity, associated with adequate monitoring of the seed production and collection process, provides seeds of high physiological quality (HIGA; SILVA, 2006).

The biometric characterization of seeds and fruits is useful information for sustainable management of native species. In view of the multiple biometric information, it is necessary to use multivariate statistical analysis, which allows to classify and qualify different populations of species simultaneously (CRUZ et al., 2011). There are several studies of genetic diversity, carried out through biometric data, with species from the Cerrado, such as pequi (Caryocar brasiliense Cambess.), Chichá (Sterculia striata A.St.-Hil. \& Naudin), and others (PEDRI et al., 2018; SANTOS et al., 2018).

The aim of this study was to characterize and verify the biometric diversity of fruits and seeds from different localities for the collection of barbatimão [Stryphnodendron adstringens (Mart.) Coville] in the North of Minas Gerais.

\section{MATERIAL AND METHODS}

The dried barbatimão fruits used in this study were collected in nine locations in the north of Minas Gerais, which include the municipalities of Botumirim (BOT), Mirabela (MIR), Brasília de Minas (BRM), Japonvar (JAP), Formoso (FOR) and Chapada Gaúcha (CHG) (Figure 1). The collections were made in August 2014 , the period of beginning of fruit ripening. The geographical coordinates of the collection points were measured in the field, with the aid of a GPS receiver (Global Position System), GARMIN type, Etrex Vista ${ }^{\circledR}$ model.

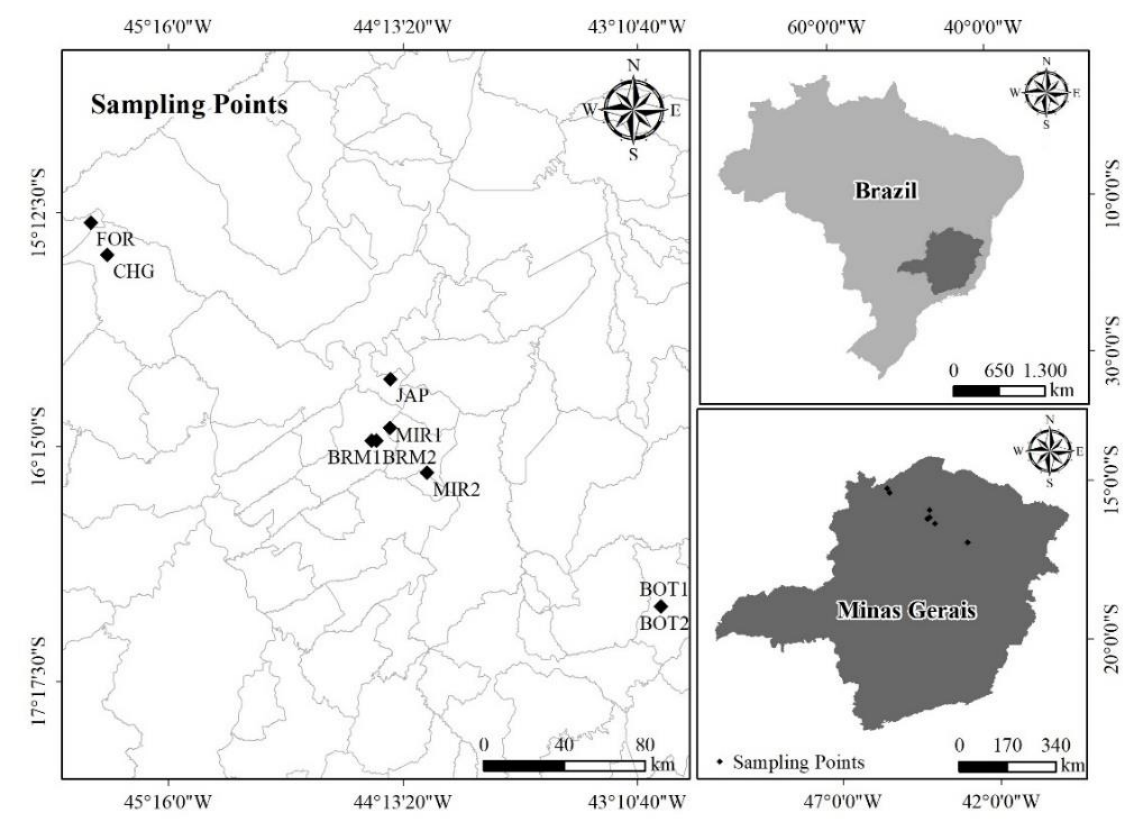

Figura 1. Localização dos pontos de coleta de sementes de Stryphnodendron adstringens (Mart.) Coville, no Norte de Minas Gerais.

Figure 1. Location of seed collection points for Stryphnodendron adstringens (Mart.) Coville, in northern Minas Gerais. 
Botumirim (BOT), Mirabela (MIR), Brasília de Minas (BRM), Japonvar (JAP), Formoso (FOR) and Chapada Gaúcha $(\mathrm{CHG})$ are located in the Cerrado biome. According to the classification of vegetation cover carried out by the Minas Gerais Ecological-Economic Zoning (SCOLFORO et al., 2016), the locations MIR1 and BRM1 are close to eucalyptus plantations, FOR and CHG belong to the same micro-region, with predominance area of Campos e Floresta Seasonal Semideciduous Montana, while BOT1 and BOT2 in transition areas of the phytophysiognomy Campo Rupestre and Campo Cerrado.

The values of average annual accumulated precipitation and the average monthly temperature, in the period between the formation of the fruit and the collection of the barbatimão seed, which occurred between the months of November to August 2014, were verified (Figure 2).

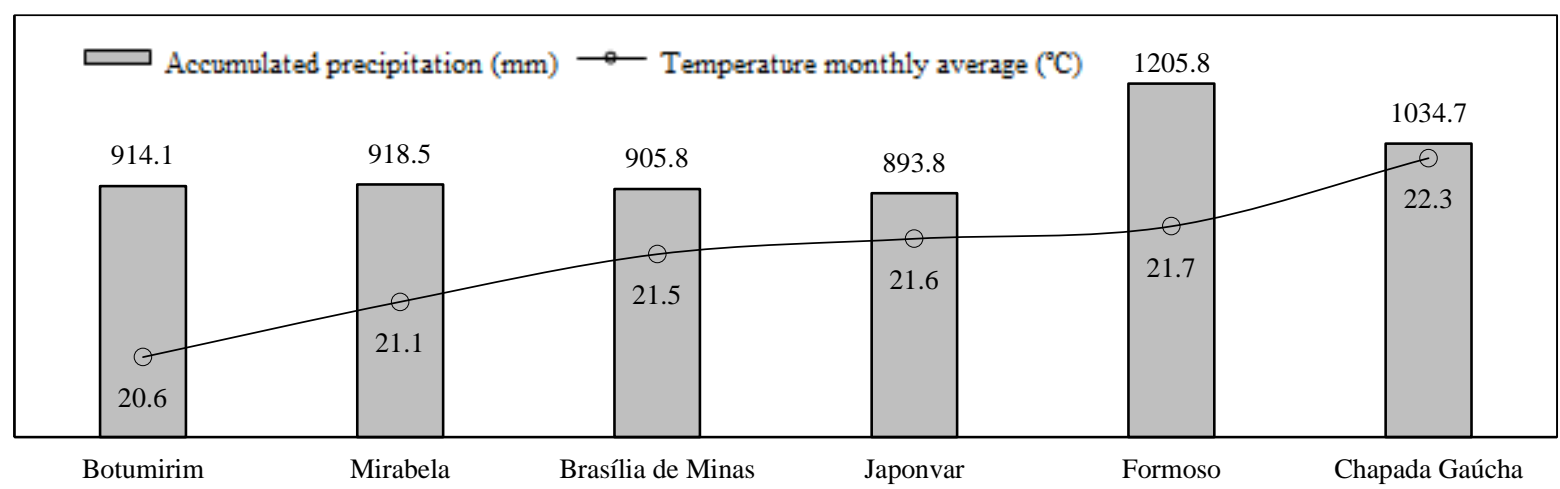

Figura 2. Valores da precipitação acumulada $(\mathrm{mm})$ e da temperatura média mensal $\left({ }^{\circ} \mathrm{C}\right)$ entre os meses de novembro e agosto de 2014, nos municípios de coleta de frutos de barbatimão.

Figure 2. Values of accumulated precipitation $(\mathrm{mm})$ and temperature monthly average $\left({ }^{\circ} \mathrm{C}\right)$ between the months of November and August 2014, in the municipalities where barbatimão fruits are collected.

Source: ALVARES et al. (2013).

To carry out the biometrics of the fruits, 30 ripe fruits (fallen on the ground) from the most accessible tree in each location were selected at random, totaling 9 trees. From these 30 fruits, of each locality, average values of length, width, weight and number of seeds per fruit were obtained, in addition to the weight of seeds, number of intact, predated and malformed seeds (without signs of predation, but not viable for germination). These evaluations were carried out at the Laboratory of Medicinal and Aromatic Plants of the Federal University of Minas Gerais, Campus Montes Claros.

The biometric data obtained were submitted to multivariate analysis of clusters, using the agglomerative hierarchical method, and to the Euclidean distance as a measure of similarity. For the elaboration of the dendrogram, the Ward connection method was used. Once the groups were obtained, they were subjected to discriminant analysis (Fisher's Linear Discriminant), in order to obtain functions that could classify the groups and test the significance of the grouping (RIBAS; VIEIRA, 2011). A factor analysis was also carried out by the principal component method using the variance-covariance matrix, to evaluate the main biometric variables of the seeds and order them in a two-dimensional system. For a better understanding, another two-dimensional ordering of the variables and seed locations was made, using the principal component analysis, using the Ideal Scale method (RIBAS; VIEIRA, 2011). The analyzes were processed with the aid of software $\bigodot$ Copyright IBM Corporation, version 20 (IBM SPSS, 2011). The number of main components was defined according to Kaiser's criteria (1958), in which he emphasizes that the components with eigenvalues greater than 1 are sufficient to represent the variance of the total data. The remaining components were ignored. 


\section{FINDINGS}

The characteristics length, width and weight of the fruit showed a low coefficient of variation (CV\%) between the nine locations, with these coefficients in the order of $10.30 \%, 9.50 \%$ and $15.70 \%$, respectively (Table 1). The highest CV estimates in this study refer to the characteristics measured in the seeds, with the greatest variation being found for the percentage of intact seeds $(50.80 \%)$, followed by the percentage of malformed seeds $(39.90 \%)$ and seed weight $(33.80 \%)$.

Tabela 1. Média, desvio padrão e coeficiente de variação das variáveis biométricas dos frutos e sementes das nove localidades de barbatimão [Stryphnodendron adstringens (Mart.) Coville], no norte de Minas Gerais

Table 1. Average, standard deviation and variation coefficient of the biometric variables of the fruits and seeds of the nine localities of barbatimão [Stryphnodendron adstringens (Mart.) Coville], in the north of Minas Gerais.

\begin{tabular}{|c|c|c|c|c|c|c|c|c|}
\hline \multirow[b]{2}{*}{ Location } & \multicolumn{4}{|c|}{ Fruit } & \multicolumn{4}{|c|}{ Seed } \\
\hline & $\begin{array}{l}\begin{array}{l}\text { Length } \\
(\mathrm{mm})\end{array}\end{array}$ & $\begin{array}{l}\text { Width } \\
(\mathrm{mm})\end{array}$ & $\begin{array}{l}\text { Weight } \\
(\mathrm{g})\end{array}$ & $\begin{array}{l}\text { Number of } \\
\text { seeds per } \\
\text { fruit }\end{array}$ & $\begin{array}{c}\text { Intact } \\
(\%)\end{array}$ & $\begin{array}{l}\text { Predated } \\
(\%)\end{array}$ & $\begin{array}{c}\text { Malformed } \\
(\%)\end{array}$ & $\begin{array}{c}\text { Weight } \\
(\mathrm{g})\end{array}$ \\
\hline BOT1 & 52,54 & 14,20 & 6,14 & 7,03 & 15,65 & 52,06 & 32,15 & 15,65 \\
\hline BOT2 & 80,19 & 14,20 & 6,14 & 5,40 & 7,96 & 49,26 & 42,59 & 7,96 \\
\hline BRM1 & 69,15 & 12,11 & 4,69 & 12,70 & 23,31 & 16,22 & 60,31 & 23,31 \\
\hline BRM2 & 76,89 & 16,74 & 7,77 & 9,36 & 43,80 & 28,42 & 34,19 & 43,80 \\
\hline $\mathrm{CHG}$ & 63,48 & 15,00 & 4,62 & 8,36 & 50,60 & 27,51 & 21,89 & 50,60 \\
\hline FOR & 83,54 & 15,89 & 5,16 & 6,93 & 21,07 & 49,49 & 32,61 & 21,07 \\
\hline JAP & 58,55 & 15,93 & 6,14 & 7,30 & 41,51 & 20,55 & 37,81 & 41,51 \\
\hline MIR1 & 75,43 & 15,59 & 5,37 & 11,13 & 67,92 & 8,09 & 23,90 & 67,92 \\
\hline MIR2 & 71,86 & 18,89 & 6,51 & 9,86 & 47,26 & 15,21 & 37,53 & 47,26 \\
\hline Deviation & 6,60 & 1,33 & 0,84 & 1,88 & 1,58 & 0,63 & 1,19 & 0,16 \\
\hline $\mathrm{CV} \%$ & 10,30 & 9,50 & 15,70 & 23,50 & 50,80 & 29,60 & 39,90 & 33,80 \\
\hline
\end{tabular}

Making a cut at a distance of 10 in the dendrogram (Figure 3), four groups of barbatimão seeds were obtained, namely: group 1 consisting of MIR1, BRM2 and MIR2; group 2 by FOR and BOT2; group 3 by CHG, JAP and BOT1; and group 4 by BRM1.

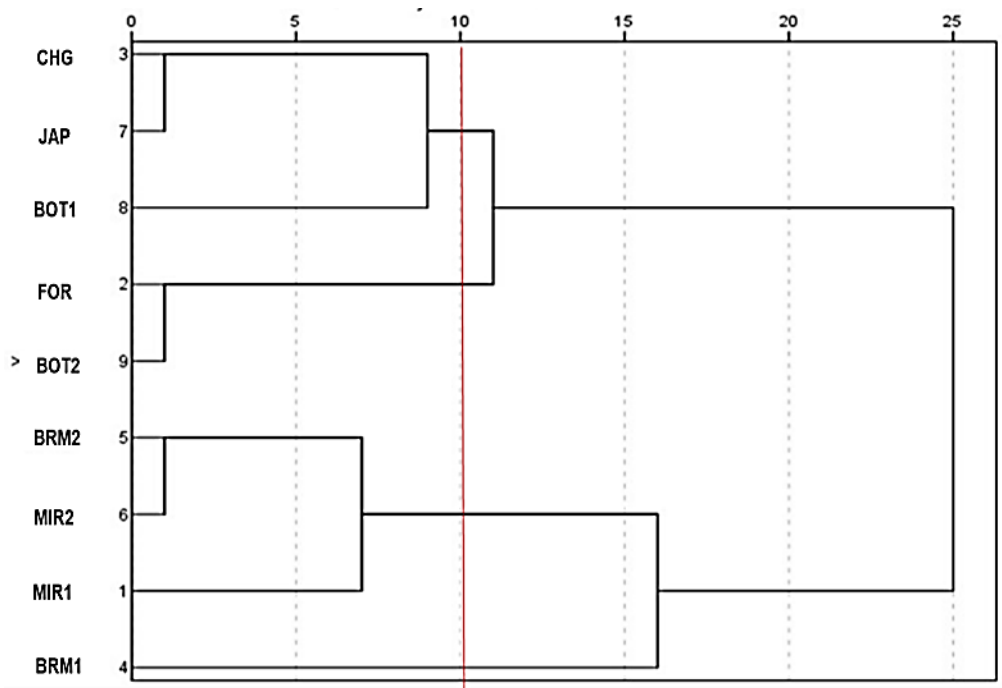

Figura 3. Dendrograma obtido pelo método de ligação Ward para seleção de grupos de nove localidades de barbatimão [Stryphnodendron adstringens (Mart.) Coville], no norte de Minas Gerais, por meio de variáveis biométricas. 
Figure 3. Dendrogram obtained by the Ward connection method for selecting groups from nine barbatimão locations [Stryphnodendron adstringens (Mart.) Coville], in northern Minas Gerais, using biometric variables.

The localities BRM2 (Brasília de Minas) and MIR2 (Mirabela), belonging to group 1, are more similar, as they joined a smaller resized Euclidean distance, while MIR1 (Mirabela), the third member of the group, differed from these localities. The three locations are geographically close, indicating the biometric similarity of the seeds. Group 2, composed of FOR (Formoso) and BOT2 (Botumirim), showed great similarity between them and, at a Euclidean distance of 11, joined Group 3. Although the two locations (FOR and BOT2) presented seeds with similar morphological characteristics, both are geographically separated. In group 3, the locations CHG (Chapada Gaúcha) and JAP (Japonvar) are quite similar to each other and join BOT1 (Botumirim) at a Euclidean distance of 9, however that location (BOT1) is geographically distantt from CHG and JAPlocations. The seeds from BRM1 (Brasília de Minas), the only component in group 4, showed greater biometric differences in relation to the other groups.

Regarding the discriminant analysis, three functions were obtained to classify groups of seed localities, with the first function representing $82,70 \%$ of the total variance, and, together with the second function, they represented $97.60 \%$ of this variance (Figure 4). These two functions were significant for classifying the groups of seeds and fruits of the barbatimão, whose canonical correlation coefficients were greater than 0.98. For the constitution of the discriminating functions, five biometric variables with discriminating power of the groups were selected, namely: length $(\mathrm{mm})$ and width $(\mathrm{mm})$ of the fruit, number of seeds per fruit, weight $(\mathrm{g})$ of the seed and number of intact seeds.

The graphic dispersion of the nine collection locations of barbatimão (Figure 4) shows the formation of four distinct groups, since the centroides are far apart. In addition, it should be noted that the greatest differences occurred between locations 2 and 4.

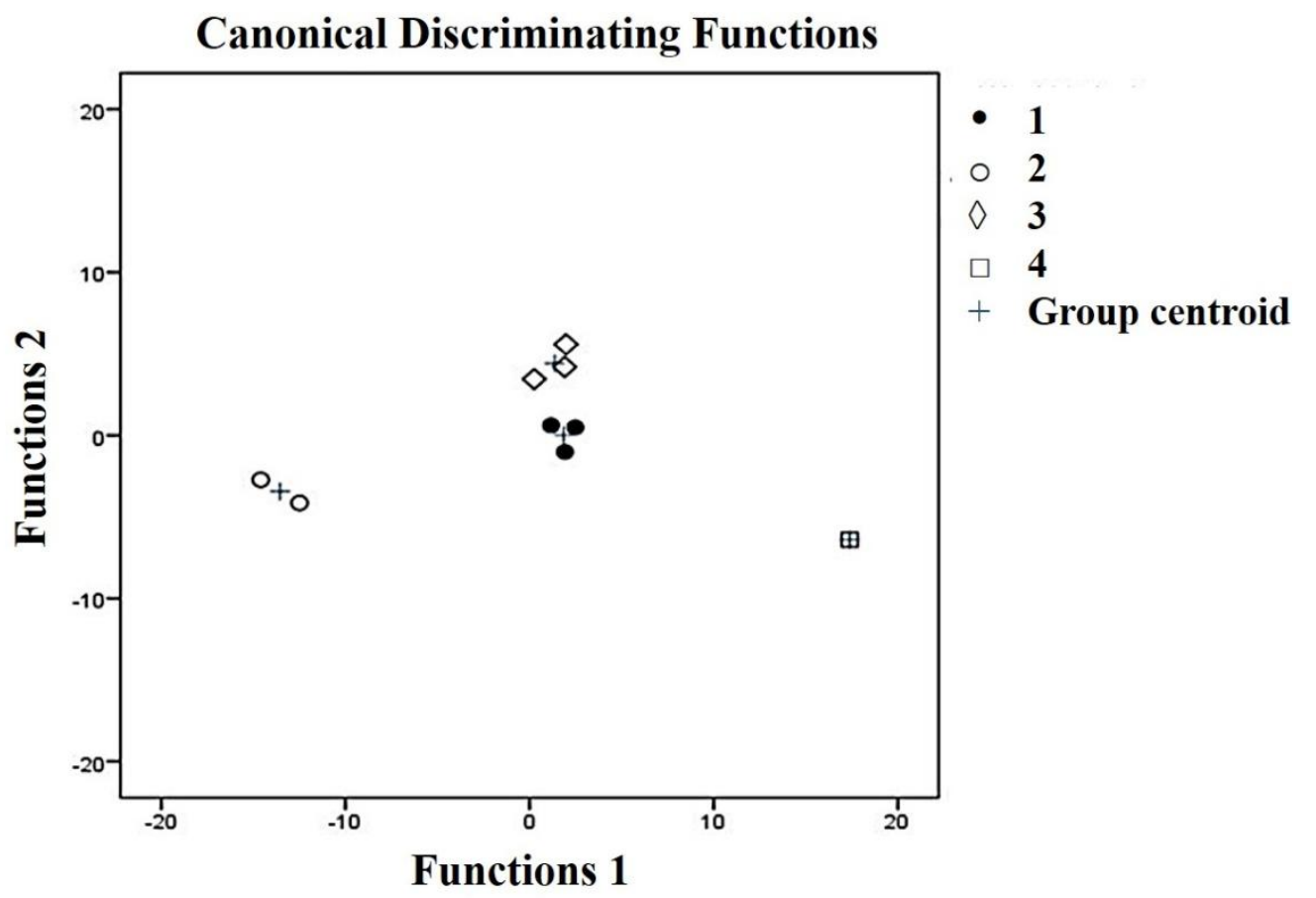

Where: 1 = MIR1, MIR2, BRM2; 2 = FOR, BOT2; 3 = CHG, JAP, BOT1; 4 = BRM1

Figura 4. Classificação dos grupos de nove localidades de barbatimão [Stryphnodendron adstringens (Mart.) Coville], localizadas no norte de Minas Gerais, pela análise de funções discriminantes canônicas padronizadas.

Figure 4. Classification of groups of nine barbatimão locations [Stryphnodendron adstringens (Mart.) Coville], located in northern Minas Gerais, by the analysis of standardized canonical discriminating functions.

FLORESTA, Curitiba, PR, v. 50, n. 2, p. 1239 - 1248, abr/jun 2020. 
Group 4, formed by BRM1 (Mirabela), positioned itself on the right side of the figure, stayed away from the other groups, thus reaffirming its difference from the others. In addition, this group presented, on average, a greater number of seeds per fruito, a greater number of malformed seeds, less weight of seeds and smaller width (Table 2).

Tabela 2. Valores médios das variáveis biométricas do fruto e de sementes de nove localidades de barbatimão [Stryphnodendron adstringens (Mart.) Coville], no norte de Minas Gerais.

Table 2. Average, standard deviation and variation coefficient of the biometric variables of the fruits and seeds of the nine localities of barbatimão [Stryphnodendron adstringens (Mart.) Coville], in the north of Minas Gerais.

\begin{tabular}{|c|c|c|c|c|c|c|c|c|}
\hline \multirow[b]{2}{*}{ GROUP } & \multicolumn{4}{|c|}{ Fruit } & \multicolumn{4}{|c|}{ Seed } \\
\hline & Length (mm) & $\begin{array}{l}\text { Width } \\
(\mathrm{mm})\end{array}$ & $\begin{array}{l}\text { Weight } \\
(\mathrm{g})\end{array}$ & $\begin{array}{c}\text { Number of seeds } \\
\text { per fruit }\end{array}$ & $\begin{array}{l}\text { Weight } \\
\text { (g) }\end{array}$ & $\begin{array}{l}\text { Intact } \\
(\%)\end{array}$ & $\begin{array}{l}\text { Predated } \\
(\%)\end{array}$ & $\begin{array}{l}\text { Malformed } \\
\quad(\%)\end{array}$ \\
\hline Group 1 & 74,73 & 17,07 & 6,56 & 10,12 & 0,72 & 53,75 & 16,70 & 31,52 \\
\hline Group 2 & 81,87 & 15,05 & 4,99 & 6,17 & 0,34 & 15,40 & 49,43 & 36,95 \\
\hline Group 3 & 58,19 & 15,05 & 4,73 & 7,57 & 0,36 & 36,86 & 32,89 & 30,25 \\
\hline Group 4 & 69,16 & 12,12 & 4,70 & 12,70 & 0,71 & 23,39 & 16,30 & 60,39 \\
\hline
\end{tabular}

Group 2, located on the left side of the graph, formed by FOR (Formoso) and BOT2 (Botumirim), is far from the other groups, thus demonstrating their difference. This group stood out for its greater length of fruits, greater quantity of preyed seeds and lesser number of intact seeds.

Groups 1 and 3 are distributed closer together on the ordering graph. This behavior indicates the similarity between them, although they are separated in the analysis of the clustering method.

Group 1, consisting of the locations MIR1 and MIR2 (Mirabela) and BRM2 (Brasília de Minas), was the one that presented seeds with greater width, greater weight, a higher percentage of intact seeds than malformed and predated seeds, therefore, it is the group that has the best biometric results.

In the factor analysis, using the principal component method, three components were selected. The selection criteria used were eigenvalues greater than 1 , which represented $85.75 \%$ of the total variance (Table 3 ). In the first main component, the variables number of seeds per fruit, seed weight, intact seeds and predated seeds showed a higher correlation. In the second discriminant function, which represents $24.84 \%$ of the variance, the variables that contributed most were fruit width and percentage of malformed seeds. In the third function, it was the length and the weight of the fruits, although these variables represent only $13.74 \%$ of the variance.

Tabela 3. Análise fatorial pelo método dos componentes principais para ordenação das variáveis biométricas das sementes de barbatimão.

Table 3. Factor analysis by the principal component method for ordering the biometric variables of barbatimão seeds.

\begin{tabular}{|c|c|c|c|c|c|c|}
\hline \multirow{2}{*}{\multicolumn{2}{|c|}{ Variables }} & \multicolumn{3}{|c|}{ Rotated loads (weights) } & \multirow{2}{*}{$h_{i}^{2}$} & \multirow{2}{*}{$\Psi_{i}$} \\
\hline & & $\mathrm{CP} 1$ & $\mathrm{CP} 2$ & $\mathrm{CP} 3$ & & \\
\hline \multirow{4}{*}{ 莺 } & Pod length (mm) & $-0,071$ & 0,081 & 0,910 & 0,840 & 0,160 \\
\hline & Width (mm) & 0,396 & $-0,723$ & 0,413 & 0,850 & 0,150 \\
\hline & Weight $(\mathrm{g})$ & 0,467 & $-0,287$ & 0,673 & 0,753 & 0,247 \\
\hline & Number of seeds per fruit & $\mathbf{0 , 7 4 3}$ & 0,633 & 0,071 & 0,958 & 0,042 \\
\hline \multirow{4}{*}{ 苂 } & Weight $(\mathrm{g})$ & $\mathbf{0 , 8 3 2}$ & 0,312 & 0,382 & 0,937 & 0,063 \\
\hline & Intact & 0,947 & $-0,062$ & 0,064 & 0,904 & 0,096 \\
\hline & Predated & $-0,872$ & $-0,003$ & $-0,001$ & 0,761 & 0,239 \\
\hline & Malformed & 0,243 & $\mathbf{0 , 8 8 8}$ & 0,090 & 0,856 & 0,144 \\
\hline \multirow{2}{*}{\multicolumn{2}{|c|}{$\begin{array}{l}\text { Eigenvalues and eigenvectors } \\
\% \text { of Variance Explained }\end{array}$}} & 3,774 & 1,987 & 1,099 & - & - \\
\hline & & 47,176 & 24,837 & 13,735 & - & - \\
\hline \multicolumn{2}{|c|}{$\%$ of Accumulated Variance } & 47,176 & 72,013 & 85,748 & - & - \\
\hline
\end{tabular}

CP: Main Components; $\mathrm{h}^{2}$ i: commonality; $\Psi_{\mathrm{i}}$ : Variance Explained 
The number of seeds per fruit, seed weight and number of intact seeds were the variables that most contributed to the classification of seed collection locations, with more than $90 \%$ of their variances, as shown by the commonality values (Table 3). Then, there were the number of malformed seeds, fruit width and pod length, with values of variance between 80 to $90 \%$.

The distribution of variables and seed collection locations in two ordering axes (main components) (Figure 5).

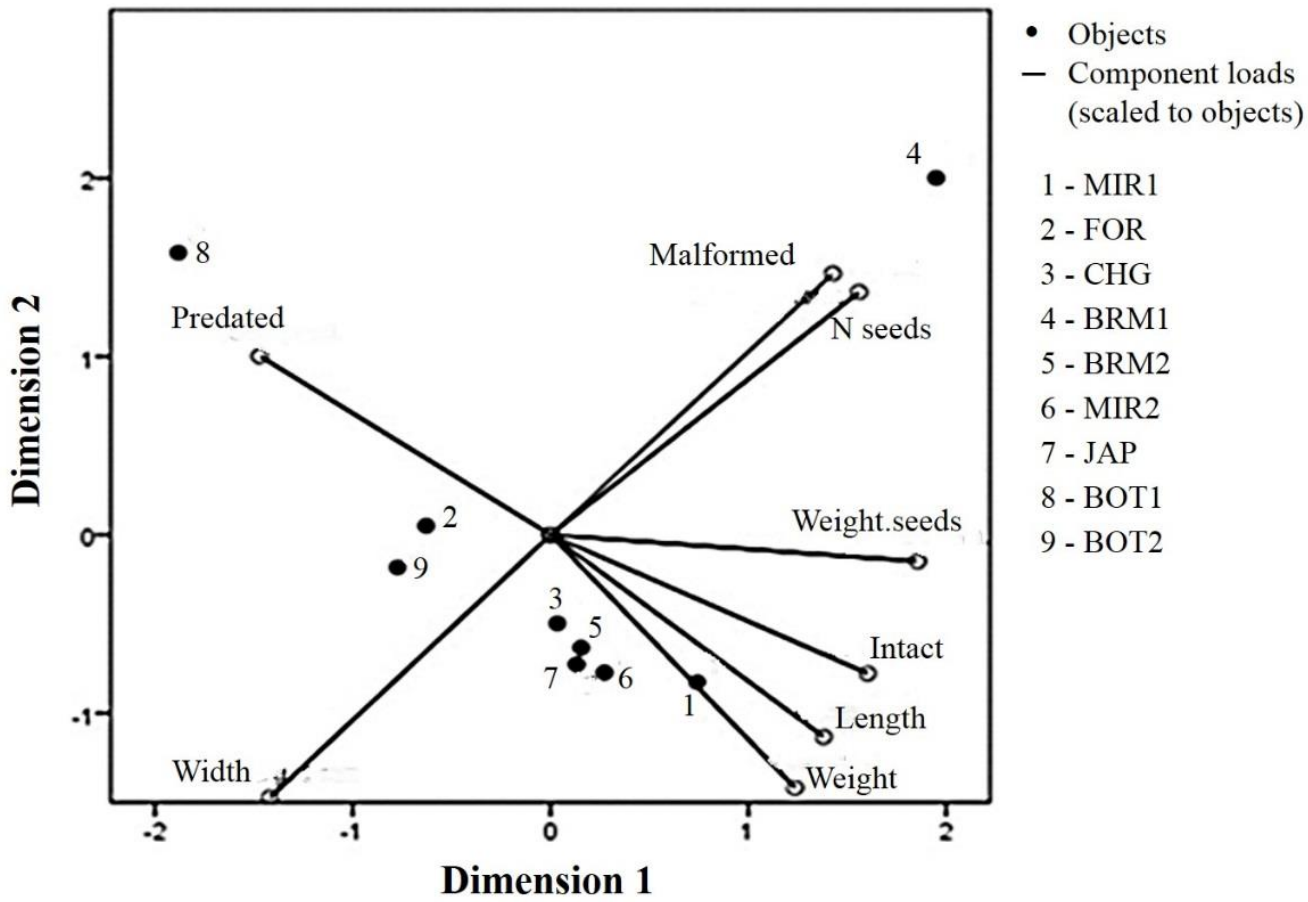

Figura 5. Componentes principais obtidos pelo método de Escala Ideal para ordenação das localidades de coleta de sementes e das variáveis biométricas.

Figure 5. Main components obtained by the Ideal Scale method for ordering seed collection locations and biometric variables.

The number of intact seeds (Without intact), seed weight (Weight without), number of seeds per fruit ( $\mathrm{N}$ without), located to the right of the sorting graph, and the variable number of predated seeds (Without pred. ), on the upper left of the graph, have a negative value, so these variables are more correlated with the first main component. The variable number of malformed seeds (Without malform), located in the upper right part of the graph, and the fruit width variable (Larg. Mm), located in the lower left part of the graph, by having negative values, are more correlated with the second main component. Regarding the variables pod length (length) and dry fruit weight (weight g), they are more correlated with the third main component and are located in the lower right part of the ordering graph (Figure 5).

It was also observed, in Figure 5, that location 4 (BRM1) is positively correlated with the number of seeds per fruit and the number of malformed seeds, thus constituting a group of seeds with lower morphological quality. Locations 8 (BOT1), 2 (FOR) and 9 (BOT2), located to the left of the graph, are positively correlated with the variable number of predated seeds (No pred.), and in these locations there was a greater attack of pests on fruits. Locations 1 (MIR1), 6 (MIR2) and 5 (BRM2), constituents of group 1, are relatively correlated with the dry weight of the fruits; and localities $3(\mathrm{CHG})$ and 7 (JAP), constituents of group 3, also somehow correlate with these variables (Figure 5)

\section{DISCUSSION}

The average biometric values of fruits and seeds are similar to other studies that used the same species, such as the study by Freitas et al. (2014), in Papagaio-MG, who found fruit length ranging from 62.1 to $69.0 \mathrm{~mm}$ and width from 11.6 to $14.5 \mathrm{~mm}$.

The seeds from BOT1 and BOT2, collected from geographically close locations (Botumirim), predominated in the largest number of predated seeds. This higher incidence of predatory insects, according to 
Correia et al. (2017), also occurs when the seeds are linked to the mother plant, in addition to the question of the species of the Fabaceae family having high rates of insect predation. According to Ribeiro et al. (2007), many species of the Cerrado have their integument damaged by the action of insects, which can contribute to the reduction of biomass. However, there are authors who mention the positive aspect of predation, when, for example, it takes into account the natural scarification process, which helps in the germination process, provided that predation does not damage the embryo and that the consumption of seed reserve is small (DONATO et al., 2010).

The number of seeds per fruit, in most locations, is in line with what is observed in the literature, which varies from eight to twelve seeds per fruit (SILVA JÚNIOR, 2005). However, there are also scientific studies with barbatimão that obtained averages close to those found in the locations of JAP (Japonvar), BOT1 and BOT2 (Botumirim) (CORRÊA et al., 2012). Environmental, chemical and physical factors influence the viability and integrity of forest seeds (MEIRA; NOBRE, 2014). This variation in the biometrics of fruits and seeds may be associated, in addition to environmental influences, to the genetic characteristics of the selected trees. According to Botezelli et al. (2000), although they belong to the same species, the plants can have an effect of natural selection, resulting in genetically adapted individuals, with certain favorable phenotypic characteristics, selected according to nutritional and environmental conditions (temperature and water availability) and dispersing and pollinating agents. These characteristics may have influenced the groupings of the localities.

The results of the multivariate analysis showed that the average number of seeds per fruit, seed weight, intact seeds and predated seeds stood out in the biometric characterization of the seeds in the studied locations, as they constituted $47.18 \%$ of the total explained variance. In addition, group 1, consisting of MIR1, MIR2 and BRM2, has positive characteristics in relation to biometric variables, which indicates the existence of morphological quality of the fruits of these locations. This result suggests that they are ideal areas for collecting seeds.

The study of biometric characteristics of fruits and seeds of barbatimão, associated with multivariate analysis, is an important tool to aid in the formation of germplasm banks, in order to improve these characteristics, as well as for seedling collection and seedling production, contributing to conservation ex situ. The grouping of locations carried out by means of multivariate analysis allows the planning of seed collection, in view of healthy parent trees in a given location, at pre-established distances.

The seeds collected in the locations FOR (Formoso) and CHG (Chapada Gaúcha) and BOT1 and BOT2 (Botumirim) are found in different and distant phytophysiognomies and, therefore, were grouped separately. FOR and BOT2 formed group 2, and CHG and BOT1 are constituents of group 3, however they have similarities because they are located near the Sub-Mountain Semideciduous Seasonal Forest and Rupestrian Fields, that is, similar environments in terms of edaphic and water conditions, but distant geographically. As shown in Figure 2, these locations have in common the highest averages of accumulated precipitation, despite showing a small difference in average temperature, in relation to the other collection points. These relationships between morphological and environmental characteristics may indicate the presence of ecotypical adaptations. These variations are related to the physiological characteristics of the trees and are directly related to the growth and survival of the plants (COLLAR et al., 2010).

The lowest average values of fruit length, weight and number of seeds per fruit were presented in group 3. This shows the relationship between the length of the fruit and the seeds, in which the smallest fruits provide the least number of seeds and with the lowest number of seeds free from predation and formation. Group 4, formed by BRM1, had a clear distinction from the other groups, because this group had the lowest quality seeds. According to Freitas et al. (2014), in addition to genetic and environmental differences, the high number of malformed seeds per fruit of tree species can be explained by the hypothesis of the limitation of resources. Thus, only studies involving the manipulation of source-drain relationships could clarify this issue. In addition, it is necessary to consider the pollination processes, pollen quality and seed dispersal, as these processes are related to the biometric characteristics of the seeds and fruits. The pollination of barbatimão is carried out by small insects, such as bees, and, when these insects are in smaller quantities, the production of seeds and fruits may be impaired, or when the availability of pollen produced by the plant is not ideal, being that dispersion reduces predation close to adult plants.

The selection of locations that are geographically close, but in different groups, such as the one in BRM1 and BRM2 and BOT1 and BOT2, can be explained by several variables that were not evaluated in the present study, among them, we can mention the genetic aspects. The genetic makeup is one of the most important factors in the formation of fruits and seeds, and in many studies they point out that the greatest genetic variability of barbatimão populations is intrapopulational, that is, they occur within the population itself (GLASENAPP et al., 2007). In this way, it is also possible to justify the selection of locations that are geographically close, but in different groups, such as what happened in BRM1 and BRM2 and BOT1 and BOT2. 


\section{CONCLUSIONS}

- The variables that most contributed to the biometric characterization of the seeds were the number of seeds per fruit, the weight of the seeds and the number of intact and predated seeds, suggesting that these variables are indispensable in biometric studies of the species.

- The barbatimão fruits and seeds that showed the best biometric characteristics were those collected in MIR1 (Mirabela), BRM2 (Brasília de Minas) and MIR2 (Mirabela). These locations are geographically close, belonging to the same similarity group, thus being the most suitable locations for obtaining matrices, for future studies and propagation of the species.

- Fruit length and weight were the characters that had less importance in this study.

- The variations in fruits and seeds were more evident within the locality than between the localities.

\section{ACKNOWLEDGMENTS}

To Isabela Reis Queiroz for her contribution to fruit collection. To the Tutorial Education Program (PETAgronomia ICA-UFMG), CAPES, CNPq and FAPEMIG, for their support.

\section{REFERENCES}

ALVARES, C. A.; STAPE, J. L.; SENTELHAS, P. C.; GONÇALVES, J. L. M.; SPAROVEK, G. Köppen's climate classification map for Brazil. Meteorologische Zeitschrift, Sttutgart, v. 22, n. 6, p. 711-728, 2013.

BORGES FILHO, H. C.; FELFILI, J. M. Avaliação dos níveis de extrativismo da casca de barbatimão [Stryphnodendron adstringens (Mart.) Coville] no Distrito Federal, Brasil. Revista Árvore, Viçosa, v. 27, n. 5, p. 735-745, 2003.

BOTEZELLI, L.; DAVIDE, A. C.; MALAVASI, M. M. Características dos frutos e sementes de quatro procedências de Dipteryx alata Vogel (baru). Revista Cerne, Lavras, v. 6, n. 1, p. 9-18, 2000.

BRASIL. Ministério do Meio Ambiente. 2018. O bioma Cerrado. Disponível em: < http://www.mma.gov.br/biomas/cerrado $>$. Acesso em: 04/10/2018.

COLlAR, D. C.; SCHUlTE, J. A.; O'MEARA, B. C.; LOSOS, J. B. Habitat use affects morphological diversification in dragon lizards. Journal of Evolutionary Biology, Zurich, v. 23, p. 1033-1049, 2010.

CORRÊA, V. S.; CERDEIRA, A. L.; FACHIN, A. L.; BERTONI, B. W.; PEREIRA, P. S.; FRANÇA, S. C.; MOMM, H. G.; MORAES, R. M.; PEREIRA, A. M. S. Geographical variation and quality assessment of Stryphnodendron adstringens (Mart.) Coville with in Brazil. Genetic Resource and Crop Evolution, Durham, v. 57, n. 7, p. 1349-1356, 2012.

CORREIA, L. A. S.; MEDEIROS, J. A. D.; SILVA, A. B.; FERRARI, C. S.; PACHECO, M. V. Qualidade fisiológica de sementes de catanduva sob infestação de Callosobruchus maculatus (Coleoptera: Bruchidae). Agropecuária Técnica, Areia, v. 38, n. 2, p. 65-70, 2017.

CRUZ, C. D.; FERREIRA, F. M.; PESSONI, L. A. Biometria Aplicada ao Estudo da Diversidade Genética. Visconde do Rio Branco: Suprema, 2011, 620 p.

DONATO, D. B.; FONSECA, A. G.; ASSIS JÚNIOR, S. L.; MACHADO, E. L. M.; BISPO, D. F. A. Dano de Caryedes sp. (COLEOPTERA: BRUCHIDAE) e seus Reflexos na Propagação de Enterolobium contortisiliquum (LEGUMINOSAE). Floresta e Ambiente, Rio de Janeiro, v. 17, n. 2, p. 118-123, 2010.

FREITAS, V. L. O.; VIEGAS, F. P.; LOPES, R. M. F. Biometria de frutos e sementes, germinação e desenvolvimento inicial de barbatimão (Stryphnodendron adstringens). Revista Floresta, Curitiba, v. 44, n. 1, p. $21-32,2014$.

GLASENAPP, J. S.; CASALI, V. W. D.; MARTINS, E. R.; CRUZ, C. D.; BARBOSA, P. B. Descrição da diversidade genética de populações naturais de barbatimão Stryphnodendron adstringens (Mart.) Coville em unidades de conservação de Minas Gerais. Revista Árvore, Viçosa, v. 38, n. 1, p. 103-112, 2014. 
HIGA, A. R.; SILVA, L. D. Pomar de sementes de espécies florestais nativas. Curitiba: FUPEF, 2006, 299 p.

IBM Corp. Released 2011. IBM SPSS Statistics for Windows, Version 20.0. Armonk, NY: IBM Corp.

KAISER, H. F. The varimax criterion for analytic rotation in factor analysis. Psychometrika, Switzerland, v. 23, n. 3, p. 187- 200, 1958.

LORENZI, H. J. Flora brasileira: Arecaceae (palmeiras). Nova Odessa: Instituto Plantarum de Estudos da Flora, 2010,368 p.

LOURENZANI, A. E. B. S.; LOURENZANI, W. L; BATALHA, M. O. Barreiras e oportunidades na comercialização de plantas medicinais provenientes da agricultura familiar. Informações Econômicas, São Paulo, v. 34, n. 3, p. 15-25, 2004.

MEIRA, M. R.; CABACINHA, C, D.; GAMA, A. T.; MARTINS, E. R.; FIGUEIREDO, L. S. Caracterização estrutural do barbatimão (Stryphnodendron adstringens (Mart.) Coville) no Cerrado do Norte de Minas. Ciência Florestal, Santa Maria, v. 26, n. 2, p. 627-638, 2016.

MEIRA, M. R.; NOBRE, D. A. C. Avaliação da qualidade de sementes de barbatimão oriundas de três locais no Norte de Minas Gerais. Revista de Ciências Agrárias, Lisboa, v. 37, n. 1, p. 50-58, 2014.

PEDRI, E. C. M.; CARDOSO, E. S.; TIAGO, A. V.; SILVA, V. P.; ROSSI, A. A. B. Variação biométrica de frutos e sementes de Sterculia striata A.St.-Hil. \& Naudin. Nucleus, Ituverava, v. 15, n. 1, p. 453-460, 2018.

RIBAS, J. R.; VIEIRA, P. R. C. D. Análise Multivariada com o uso do SPSS. Rio de Janeiro: Ciência Moderna, $2011,272 \mathrm{p}$.

RIBEIRO, M. L.; SALES, V. A.; MIRANDA, F. S.; SOARES, C. E. A.; OLIVEIRA, S. C. C. Influência da predação de sementes na germinação de leguminosas (Fabacea) no Cerrado, Nota Científica. Revista Brasileira de Biociências, Porto Alegre, v. 5, n. 2, p. 279-281, 2007.

SANTOS, P. H. R.; GIORDANI, S. C. O.; SOARES, B. C.; SILVA, F. H. L.; ESTEVES, E. A.; FERNANDES, J. S. C. Genetic divergence in populations of Caryocar brasiliense Camb. from the physical characteristics of the fruits. Revista Árvore, Viçosa, v. 42, n. 1, p. 1-8, 2018.

SCOLFORO, J. R.; OLIVEIRA, A. D. de; CARVALHO, L. M. de; MARQUES, J. J. G; LOUZADA, J. N.; MELLO, C. R. de; PEREIRA, J. R.; REZENDE, J. B.; VALE, L. C. C. Zoneamento Ecológico-Econômico de Minas Gerais. Lavras: UFLA, 2016. 15 p. (Capítulo 1). Disponível em:< http://www.zee.mg.gov.br/>. Acesso em 09 jun. 2018.

SILVA JUNIOR, M. C. 100 árvores do Cerrado: Guia de Campo. Brasília: Rede de Sementes do Cerrado, 2005, $221 \mathrm{p}$. 